\title{
Management of non-value-added activities to minimize lead time using value stream mapping in the steel industry
}

\author{
Pandian R. SUDHAKARA ${ }^{1}$, Robert SAEEK ${ }^{2}$, Dhanashri VENKAT ${ }^{3}$ and \\ Katarzyna CHRUZIK ${ }^{4}$
}

Authors' affiliations and addresses:

${ }^{1}$ Vellore Institute of Technology, Vellore, India

e-mail: sudhame@gmail.com

${ }^{2}$ Częstochowa University of Technology,

Czestochowa, Poland

e-mail: robert.salek@wz.pcz.pl

${ }^{3}$ Vellore Institute of Technology, Vellore, India e-mail: dhanashri.v2017@vitstudent.ac.in

${ }^{4}$ Faculty of Applied Sciences, WSB University e-mail:kchruzik@wsb.edu.pl

*Correspondence:

Pandian R. Sudhakara: Częstochowa University of Technology, Armii Krajowej 19B, 42-201

Częstochowa, Poland

tel.: 0048342350330

e-mail: robert.salek@wz.pcz.pl

How to cite this article:

Sudhakara, P. R., Sałek, R., Venkat, D. and Chruzik, K. (2020). Management of non-valueadded activities to minimize lead time using value stream mapping in the steel industry. Acta Montanistica Slovaca, Volume 25 (3), 444-454

DOI:

https://doi.org/10.46544/AMS.v25i3.15

\begin{abstract}
Value Stream Mapping is an efficient and powerful tool of the Lean Manufacturing system that helps in eliminating Non-Value-Added activities (NVAs) in a process by clearly exposing the areas where there is waste in the Value stream (Information and material flow). Value Stream Mapping is a standardized way to document the steps in a process and systematically analyze the steps to develop improvement plans. The "current state map" is a foundation for the improved "future state map" that is developed after eliminating the NVAs identified in the current state map and thereby decreasing the lead time. It can be implemented not only in manufacturing sectors but also in many different sectors such as IT sectors, Healthcare sectors and government service sectors to identify and eliminate the processes or operations that do not add any value to the product or in other words, the processes for which the customer is not willing to pay. The main objective of this work is to study the process flow of a part family in a steel industry located in Southern part of India using value stream mapping and eliminate the NVAs in the process by making some process and layout changes which will reduce the lead time and increase the profit of the organization. First, suitable value stream mapping is carried out for parts with similar kinds of existing manufacturing processes. Then all the NVAs present in the flow of the process are identified. Then, certain changes, such as converting the manufacturing layout into a cellular manufacturing layout and introducing continuous heat treatment processes, are made in order to eliminate the NVAs. The total lead time reduction for each part varies from 14.55 hours to 33.41 hours which is a significant amount of reduction. This paper also reviews the existing literature on Value Stream Mapping and how its implementation helps organizations successfully eliminate the waste and take them towards becoming a successful Lean Enterprise.
\end{abstract}

\section{Keywords}

Value Stream Mapping, Non-Value-Added activity, Lean Manufacturing Tool, Part family, Lead Time and Inventory

(c) 2020 by the authors. Submitted for possible open access publication under the terms and conditions of the Creative Commons Attribution (CC BY) license (http://creativecommons.org/licenses/by/4.0/). 


\section{Introduction}

Today, the competition among the industries has increased so much that there is a pressure for the manufacturing industries to reduce the lead time of products and services and the cost associated with NonValue-Added Activities that include the following seven types of wastes: Waiting, over-processing, defects, overproduction, excess inventory, transportation and excess motion (Norton and Fearne, 2009; Krykavskyy, et al., 2019 ; Oláh et al., 2017a; Kocsi and Oláh, 2017b) The pressure can be higher in service organization as the customers can easily change the service providers. The consumer expectations are high, and therefore the companies must be quick to adapt in order to provide customer satisfaction (Nwabueze and Mileski, 2018; Locher, 2008; Zimon, 2017; Pisar et al., 2019).

Toyota Production System (TPS) has contributed towards a new paradigm of manufacturing with its manufacturing principles that was coined as "Lean Manufacturing" in the book, "The Machine that changed the world" in 1991 (Womack and Jones, 2007). Since then these Lean principles were adopted by many companies all over the world in order to increase the value and profit of their company by eliminating the waste (the seven kinds of waste mentioned in Lean production principles) and maximizing the efficiency. There are several tools for the implementation of lean principles in a company (Mazur and Momeni, 2019; Tranet et al., 2020; Rajnoha et al., 2018). Value Stream Mapping is one of the powerful lean manufacturing tools to analyze the material and information flow which makes the NVAs in the value stream visible through "the current state map". It helps the organization identify the improvement opportunities in the process and develop an action plan to implement the development ideas. Value Stream is all the actions in the production flow from the raw material to the customers' hands. Value Stream Mapping is a standardized way to document the steps in a process and systematically analyze the steps to develop improvement plans (Jeong and Yoon, 2016). The "current state map" is a foundation for the improved "future state map" that is developed after eliminating the NVAs identified in the current process and thereby decreasing the lead time. Besides lead time, it also reduces the cost by eliminating the additional costs involved in performing NVAs (Klimecka-Tatar, 2018).

In this paper, the technique Value Stream Mapping (VSM) is used to analyze the process of manufacturing eight different parts from the manufacturing industry and reduce the Lead Time by making some improvement plans like changing the production system from Batch production to single-piece flow and increasing the facilities available. The steel industry is located in South India. It produces precision tooling components such as collets, honing mandrels, holding tools, jigs and fixtures. Today, the Swiss lathe collections and guide Bushings are exported worldwide, satisfying the Swiss turning needs of end customers belonging to various fields such as Defense, Automobile, Textiles, Space, Electronics, Watches, Medical, etc. Castings and billets are outsourced, and all the machining processes are done in the industry. These processes include Milling, Grinding, Heat Treatment, OD Grinding, ID Grinding, and Surface finishing along with slitting and brazing. For Steel Collet with V Line, after the billets are received, turning operation is performed. After this, face milling is done for a smooth surface. Then the part is hardened and tempered. After heat treatment and OD Grinding, slitting operation is performed to make the keyways. Then the part is sent outside for performing wire cutting operation. After receiving the part from the wire-cutting operation, ID Grinding operation is performed. At last surface, finishing is performed to ensure the desired smooth surface. For Steel Collet, the same manufacturing process is followed, but the wire-cutting operation is not performed for this part. For Guide Bush, the first operation performed is the milling operation. Then the batch is sent for heat treatment. After this, Brazing is performed to fix the washer. Then OD Grinding and ID Grinding are performed. Finally Lapping and Surface polishing are performed. For feed finger, all the processes other than Brazing and OD Grinding are performed. All parts have many similar processes, and they can be categorized into a product family. The analysis has been done based on the data provided by the company, which is located near Coimbatore, South India. Current and Future State maps were drawn for the manufacturing process of each of the products and improvements were suggested based on the analysis.

\section{Literature review}

Though value stream mapping (VSM) technique was first invented in Toyota Production System, the term "Value Stream Mapping" was first introduced by Womack and Jones (2007) in their book, "The Machine that changed the World". Later Rother and Shook (2009) wrote in detail in the book, "Learning to See" about Value Stream Mapping. In 2002 Kevin J. Duggen wrote a book called "Creating Mixed Model Value Stream". In this book, the author has explained the mapping techniques for complex value streams in which multiple product families with shared resources. These techniques can be used in organizations with a high product mix. Duggan and Healey, (2016) suggested a method to achieve operational excellence in an organization which is much more than eliminating the waste.

Saraswat and Kumar (2014) applied VSM in a Bearing industry. They conducted time studies on the shop floor and developed a current state map using the Edraw Software for the product families. From the map, it was 
found that two particular processes (Annealing and NC Machining) had higher cycle time and WIP. Takt time was calculated as $95 \mathrm{~s}$. So the number of workstations was increased along with some operational changes and line balancing in order to reduce the WIP. $5 \mathrm{~S}$ was implemented to solve the problems in material handling. Finally, a future state map was drawn. The lead time was reduced from 7.5 days to 3.8 days. Process time was reduced from 409 seconds to 344 seconds.

Doğan and Unutulmaz (2014) implemented a simulation-based value stream mapping in the physical therapy and rehabilitation department of a public hospital in Turkey. This study aimed to show how a healthcare organization can use VSM for evaluating itself and increasing its efficiency. Simulation technique (Arena software was used) was combined with VSM since VSM is a static tool and is less efficient in a dynamic system. The data was collected by making observations and discussions with the staff, and a current state map was drawn, and step by step process timing was simulated. They used non-value-added time (NVAT) per patient, Transfer time (TT), Length of stay (LOS) as the metrics for calculation. Subsequently, improvements were made, and two future state maps were drawn. As a result, NVAT was reduced by 38 per cent in the first proposed FSM model, and it was fully eliminated in the second proposed model. LOS was also reduced by one per cent.

Forno et al. (2014) have studied the difficulties and limitations in applying the value stream mapping and have suggested future work for improving the application of VSM. They had stated that VSM when applied wrongly might lead to many mistakes; hence, it is important to study application problems. They stated that product, process and people are the three primary causes and suggested solutions to eliminate these problems,

Santosh B.Dighe and Abhay Kakirde (2014) define Value Stream mapping as a Lean Manufacturing tool to plan a lean initiative production process through systematic data capture and analysis. They used value stream mapping to implement lean manufacturing in a pump manufacturing company. The analysis matrix, including both product quantity and revenue, has been used, and the "three phase monoblock "pump was selected for the study. For this, customer demand and Takt time were calculated. Then, the CSM showing the material and information flow were drawn. It was observed that the lead time for the product is 54 days, inventory is 33 days, and the value-added time is just 0.55 hours which shows that there is a lot of NVA. Then the opportunities for improvements were identified. Cycle time v/s Takt time graph was drawn in order to make decisions as to where to improve. Future state maps were drawn with changes such as a single piece flow model and pull process system to support the implementation. After the changes, the lead time was reduced to 36.5 days and the inventory reduced to 22.4 days (Ashif et al., 2015).

VSM using pencil and paper is a static tool. Therefore it cannot be used in dynamic systems in which the processes keep changing often. Hence simulation can be used as a supporting tool for VSM. Also, using simulation reduces the total time taken for the VSM process (Chen and Meng, 2010). Current state and future state model can be created in simulation software such as Arena, and the alternative models of FSM can be simulated, and the optimum model can be selected for the implementation process.

Schmidke, Heiser \& Hinrichsen (2014) developed a simulation enhanced value stream mapping approach covering an exhaust gas purification catalyst production process to study the optimization of complex production environments. A VSM that uses Discrete Event Simulation (DES) was developed and the lead time was efficiently reduced from 11.4 days to 1.4 days (Schmidke, Heiser \& Hinrichsen, 2014)

Pandya Hardik \& Shah Sagar (2015) implemented Lean Manufacturing using VSM in a crankshaft manufacturing system at an Automotive Industry. They used Value Stream mapping to identify the waste in the industry, and after identifying the waste, they used continuous improvement or Kaizen to reduce the wastes such as high cycle time, transportation waste, rework and breakdown. They observed the current state map and made some improvements such as changing the process layout into a "U" shaped one from a "zigzag" one. Single piece process flow was established. Future state map was used to construct the improvements. Finally, the processing time was reduced from $5289 \mathrm{~s}$ to $5184 \mathrm{~s}$. The lead time was reduced from 3.22 days to 2.62 days. Transportation time was reduced from $48.73 \mathrm{~min}$ to $17.03 \mathrm{~min}$. Productivity was increased from 2000 Piece/month to 2500 Piece/month.

Joshi (2020) has applied the concepts of value stream mapping in the motor industry. All the processes involved in the production were studied and the data such as the number of operators, cycle time, set up time, etc. was collected for every process. Using the current state map, it was discovered that waiting time, set up time and transport time were the major wastes. After this, the current state map was drawn in order to visualize the improvements. The major improvement was that the cycle time was reduced from 14.9 days to 9.5 days.

Jeong and Yoon (2016) presented a paper in the application of Value Stream Mapping to implement lean in a leading IT firm that faced problems in delivering services like database provisioning. The purpose is to reduce product delivery time. This shows the wide application of VSM apart from the manufacturing industry. They have mentioned that the Lean approach is a cost-effective, agile and flexible process in an IT business and management sector. They prepared the current state map by interviewing the firm's employees who described the firm's existing problems. The whole process was divided into three stages: Planning, Execution and Quality assurance and handover. For each stage, the process map was drawn, and NVA was identified. Changes such as 
automation of planning phase and script for backup specification and standardizing the quality checking and handover process to eliminate the NVA and a future state map were created. Total lead time dramatically reduced from 31.5 days to 2.4 days.

Gergin et al.(2017) did a study in Atlasglobal Airlines in Istanbul, Turkey. The study was conducted to analyze the Airlines' ground operations and implement lean concepts through value stream mapping and upgrade the ground service quality for the passengers of the airlines. The current state map was drawn for both departure and arrival of flights after observing the ground handling services for one week. Few improvements were made in the check-in area, such as relocating the baggage weighing scale, increasing the number of check-in officers. During arrival, the baggage dispatch time was reduced by increasing the number of workers at the baggage hall. These changes led to $8 \%$ decrease in the lead time during the departure of the flight and a $23 \%$ reduction in the lead time during arrivals.

Carmignani (2017) used Value Stream Mapping to improve the supply scrap management process. A new methodology called Scrap Value Stream Mapping was developed to overcome the limitations of Value Stream Mapping in the management process. This work's objective is the speedy identification of the scrap components and returning them to the vendor.

Haung et al. (2019) developed a multi-agent system with Arduino and Raspberry pi equipped with the Cyber Physical System (CPS) for implementing Dynamic Value Stream Mapping in the SMEs (Small and Medium scale Enterprises). This cyber-physical multi-agent system helps in the virtualization of the shop floor operations. The implementation of Lean and VSM concepts in enterprises often encounters barriers, the analysis of problems in the implementation of the lean concept in the metal industry is described in the works (NowickaSkowron and Ulewicz, 2016; Maszke, 2018).

\section{Value Stream Mapping in the Steel Industry}

India is one of the pioneers in the steel industry. The products thus manufactured in these industries are being exported to many other countries. This paper aims to make a survey of the process flow and calculate the lead time using Value stream mapping for some of the parts being manufactured in South Indian industry manufacturing steel parts (as mentioned below). Firstly, for the products taken into account for this work, value stream mapping is applied.

Data collection for VSM in Steel Industry:

The data have been collected from a south India based steel industry. The following eight steel parts were selected for the study purpose;

Guide Bush (P1)

Steel collet (P2)

Steel Collet with V Line (P3)

Feed Finger (P4)

Pillar (P5)

Guide Pin (P6)

Back Stop (P7)

Clamping Head (P8)

The above four products have been chosen because of their similarity in operations and process flow. After choosing the products, the following data are collected: i) Cycle time, ii) Change over time, iii) Waiting time between each process, iv) Number of machines, v) Transportation time and, vi) Batch quantity (Pandian, and Soltysova, 2018; Nguyen, 2018).

Then, the "Current State Map" is drawn for the parts (P1 - P8) using the collected data and lead time (for processing a single batch) is calculated based on the processing time (ti) in each facility (PR) with the cycle time $(\mathrm{C} / \mathrm{T})$ for each part as mentioned in Table 1. NVAs are identified, and improvements are suggested to reduce the lead time and cost and also increase the efficiency of the whole process. Then a "Future State Map" which represents the process after the implementation of the improvements is drawn. 
Processing Time:

Tab. 1. Cycle Time

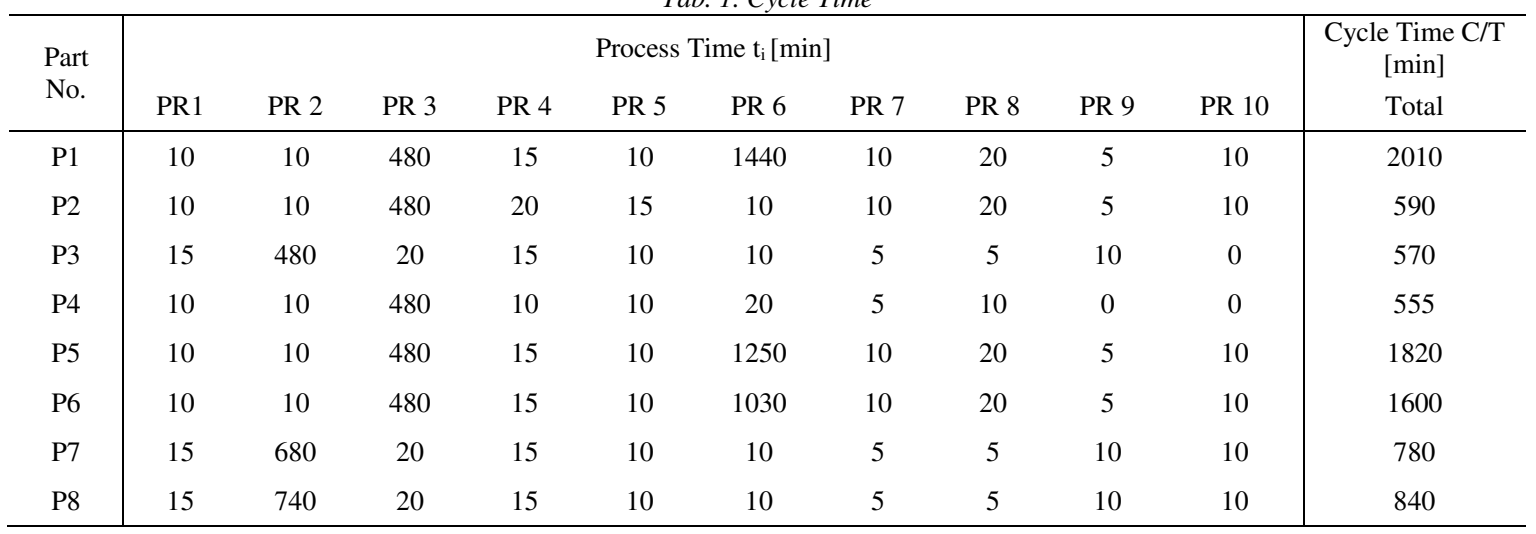

PR-Process

For study purposes, the sequence of processing of the parts is given by P1-P2-P3-P4-P5-P6-P7-P8 based on the priority of customers' orders. The sequence can be changed anytime by the management based on the order requirement. Process Time for each part is calculated. The processing time for P4 is shown in Table 2. The waiting time is calculated during the batch of parts waiting for its turn in a facility (PR). In this work, the batch size for each part is taken as 40 numbers from the industrial data.

Tab. 2. Process Time for Feed Finger (P4)

\begin{tabular}{|c|c|c|c|c|c|c|}
\hline Process & $\begin{array}{c}\text { Cycle Time } \\
\text { [min] }\end{array}$ & $\begin{array}{l}\text { Total Time for the } \\
\text { batch [min] }\end{array}$ & $\begin{array}{c}\text { In Time } \\
\text { [min] }\end{array}$ & $\begin{array}{l}\text { Out Time } \\
\text { [min] }\end{array}$ & $\begin{array}{l}\text { Waiting Time } \\
\text { [min] }\end{array}$ & $\begin{array}{c}\text { Change Over Time } \\
\text { [min] }\end{array}$ \\
\hline Turning & 10 & 400 & 800 & 1200 & 800 & 20 \\
\hline Milling & 10 & 400 & 1400 & 1800 & 600 & 15 \\
\hline Heat Treatment & 480 & 480 & 2040 & 2520 & 240 & 15 \\
\hline Slitting & 10 & 400 & 2520 & 2920 & 0 & 15 \\
\hline ID Grinding & 10 & 400 & 2920 & 3320 & 0 & 20 \\
\hline Surface Finishing & 20 & 800 & 3320 & 4120 & 0 & 15 \\
\hline QC & 5 & 200 & 4120 & 4320 & 0 & 15 \\
\hline Packing & 10 & 400 & 4320 & 4720 & 0 & 20 \\
\hline
\end{tabular}

The following is an example (Figure 1) for the present state map using value stream mapping is drawn for the product Feed Finger $(\mathrm{P} 4)$ to reflect the existing flow of the process. Then the total lead time for each batch is calculated for the respective part. Then, present state VSM for part 4 (P4) is taken as an example, and the lead time for this part is calculated as 200.91 hours, as shown in figure 1. However, the value-added time is just 58 hours only. 
Present State Map for Feed Finger (P4):

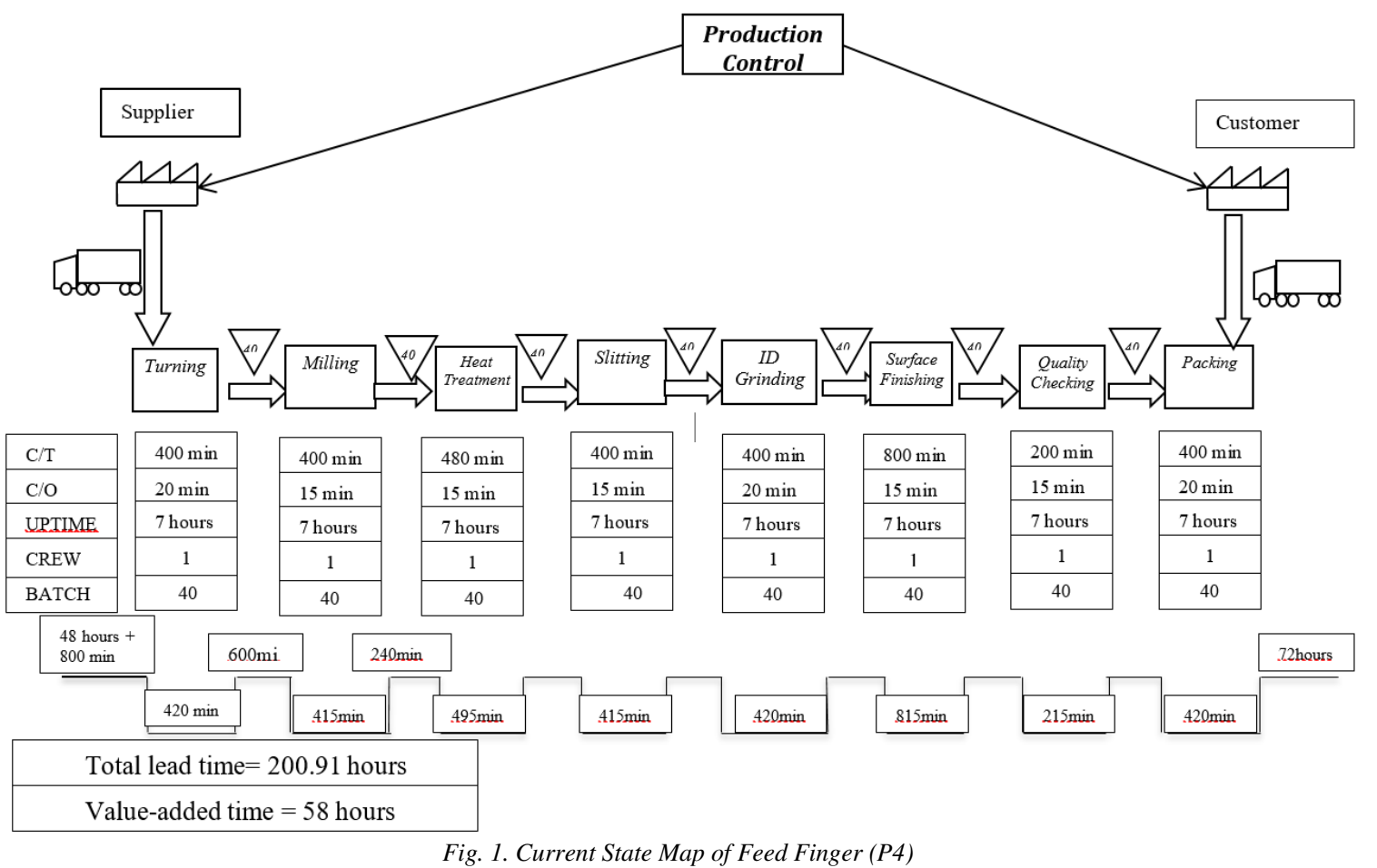

In all the VSM maps discussed in this study, the transport time between the supplier and the steel industry is considered as 48 hours. The transport time between the steel industry and the customer has been taken as 72 hours included for all the batches while calculating the lead time, as shown in Figure 1 (right and left side).

\section{Methodology}

The primary objective is to minimize the total lead time of all the parts (P1- P8) considered for this study from a south Indian steel industry in the category of small and medium enterprises. The lead time for all the parts are noted down in the existing system that includes Processing Time $\left(\mathrm{t}_{\mathrm{i}}\right)$ Idle Time and Transport Time

After noting down the lead time from the current state map, the following Non-Value Added activities (NVAs) are found out by observation. The future state value stream mapping is drawn and the new lead time calculated as shown in figure 2 .

- NVAs identified that consume additional time and cost:

- The waiting of batch of parts consumes a lot of time between each process,

- The time taken for transporting the batch of parts from one facility to another facility,

- The inventory cost of each batch of parts near each facility.

From the current state map, it can be clearly seen that the lead time can be reduced in various processes as value-added time is very less than the total Lead Time. Cellular Manufacturing and Single Piece Flow are strongly suggested before getting into future value stream mapping so that the lead time and work in process inventory will be considerably minimized. For defining the cells, rank order clustering can be performed. A code was developed for rank order clustering for making the calculations easier. By dividing the products into machine cells, and implementing a single piece flow, the waiting time can be substantially reduced. By using rank order clustering (King, 1980), the grouping of similar machines required for processing similar operations is grouped, as shown in Figure 3. 


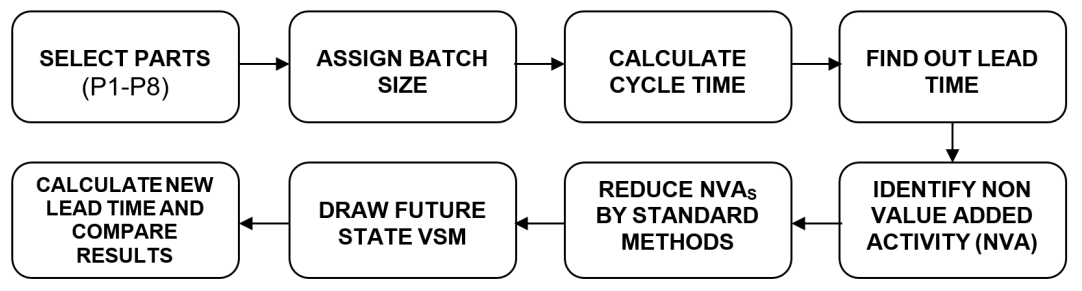

Fig. 2. Flow diagram of a suggestive method to eliminate NVAs

The following steps can be given priority measures while implementing Future VSM, (i) Precision lathe, Milling Machine, Grinding machine (ID), Grinding machine (OD), Slitting machine and polishing machine can be grouped in one cell using rank order clustering (King, 1980) [1]. (ii) Manual acetylene torch, punch polish and polishing wheel in another cell, (iii) Implementing single piece flow instead of batch production in appropriate operations. The reduced lead time is due to the elimination of waiting time between each process. Also, due to the single-piece flow, there will be a huge reduction in inventory before each process, even though it is not eliminated completely due to the differing processing time.

Based on the recommendation, the following machine cell has been created with the suggested number of machines in various categories as given in figure 3

The number of machines available should be increased for the following processes as in Table 3, which in turn would save the processing time of different batches of the same part and also processing time between various parts.

There should be two furnaces for the hardening and tempering processes in the first machine cell, as shown in Figure 3, since the process takes a longer time.

Hardening and tempering furnaces can be used continuously.

\begin{tabular}{c|c}
\multicolumn{2}{c}{ Tab. 3. Machine Numbers } \\
\hline Process & Number of Machines \\
\hline Turning & 3 \\
Milling & 3 \\
Heat Treatment & 2 \\
OD Grinding & 2 \\
Brazing & 2 \\
\hline
\end{tabular}

The part can simultaneously do its operations on different machines so that the total processing time will be reduced; thereby the lead time can be minimized that can be evident from the future state value stream mapping as shown in figure 4, drawn for the part 4 (P4) as an example.

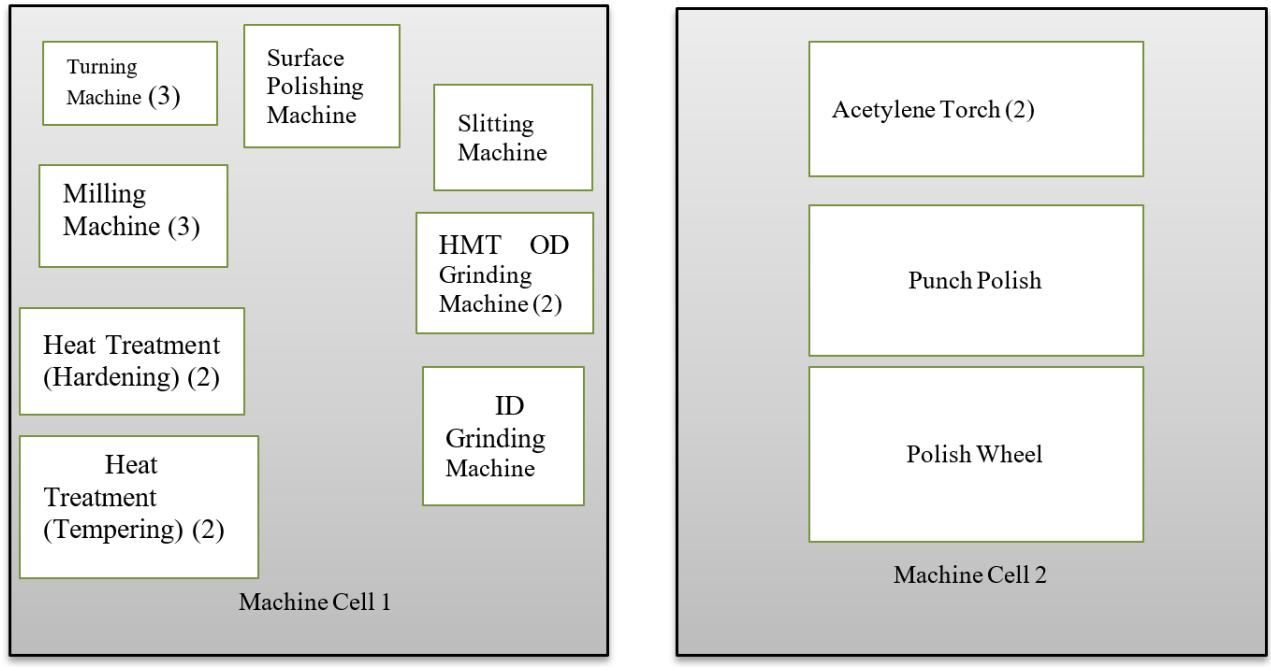

Fig. 3. The proposed layout of facilities using ROC (King and J.R. King, 1980)

Future State Map for Feed Finger (P4):

The future state VSM shown in Figure 4 after reducing the non-value added activities as mentioned in the methodology section. 
From Figure 4, it is clearly understood the total lead time has come down to 149.25 hours for part 4 (P4), which was originally calculated as 200.91 hours. So it has been reduced to 25.71 hours in its NVAs. Similarly, for all the parts from P1 to P8, the future state VSM has been drawn after applying the proposed methodology. It was found out that lead time could be minimized after reducing the NVAs in all possible areas like transport and inventory since the implemented cells provide the way to drastically reduce the processing time by parallel processing many operations of the parts considered in the study.

This will reduce the processing time for heat treatment to 1.5 hours. Since there are two tempering processes, it will take 3 hours in total. This will also reduce the inventory between the processes. Further, it will reduce the unnecessary transport of the parts between the processes.

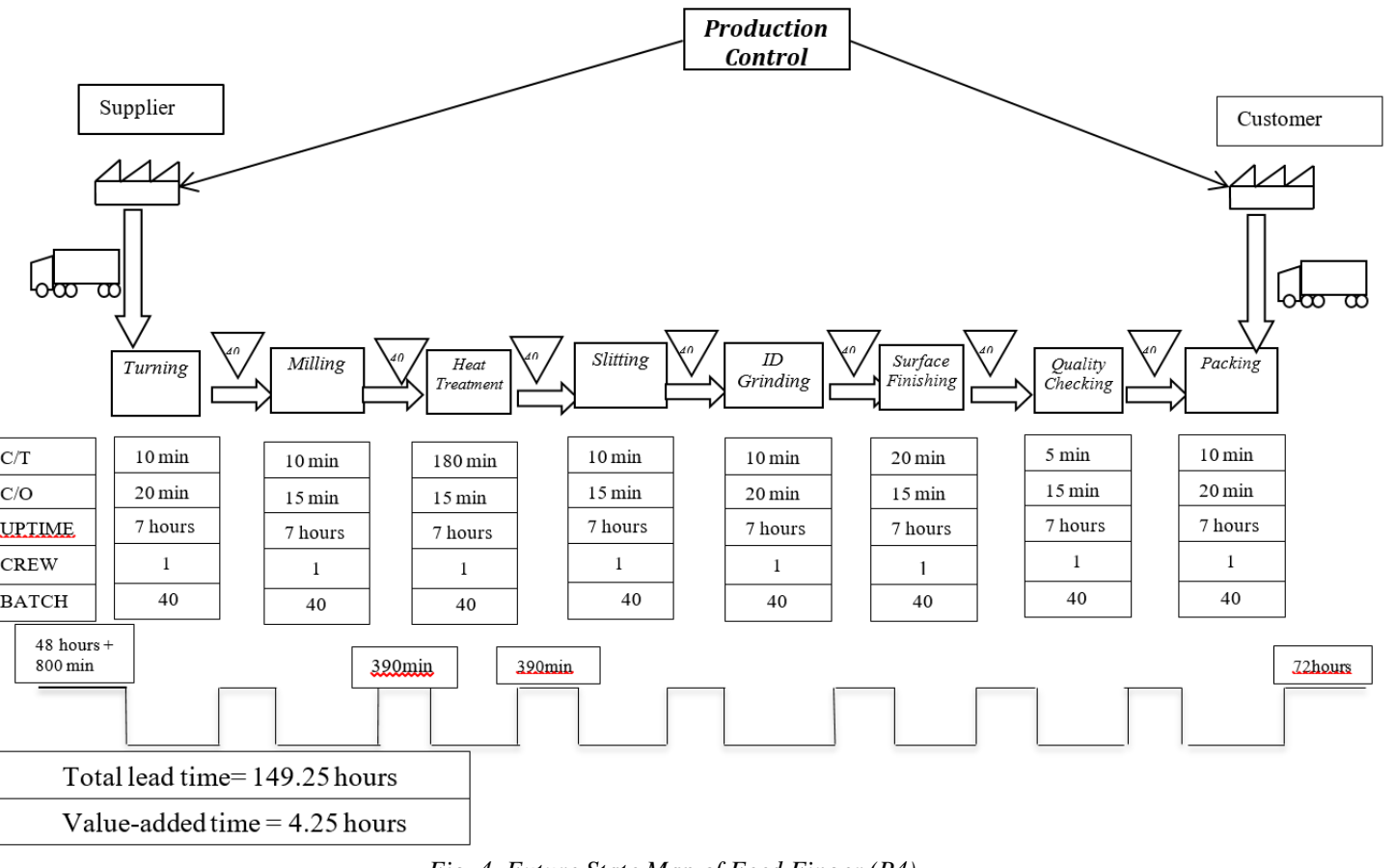

Fig. 4. Future State Map of Feed Finger (P4)

\section{Results}

In this study, eight parts $(\mathrm{P} 1-\mathrm{P} 8)$ are considered for study purposes to make an attempt in minimizing total lead time using VSM by eliminating NVAs. It is clearly shown from the comparison (Table 4) of existing lead time and the lead time calculated after eliminating NVAs for all the parts that there is a considerable reduction in lead time in all the parts. However, it depends on the part feature, size and various operations present there is a variation among the reduction in the lead time of parts with a maximum lead time reduction being 33.41 percentage (Steel Collet with V Line, P3) and the minimum of 10.92 (Guide Pin, P6) percentage since these two are entirely different parts having dis-similar operations and processing times.

Tab. 4. Comparison of Lead Time

\begin{tabular}{c|ccc}
\hline Part No. & $\begin{array}{c}\text { Lead Time in hours } \\
\text { (Existing method) }\end{array}$ & $\begin{array}{c}\text { Lead Time in hours } \\
\text { (Proposed Method) }\end{array}$ & Percentage Reduction in Lead time \\
\hline P1 & 190.75 & 163.00 & 14.55 \\
P2 & 215.83 & 156.91 & 27.29 \\
P3 & 234.75 & 156.33 & 33.41 \\
P4 & 200.91 & 149.25 & 25.71 \\
P5 & 254.65 & 188.53 & 17.96 \\
P6 & 195.46 & 175.86 & 31.68 \\
P7 & 287.38 & 196.35 & 27.39 \\
P8 & 248.55 & 180.46 & \\
\hline
\end{tabular}

The comparison is shown using a bar diagram with lead time using present state VSM and lead time using future state VSM, as shown in Figure 5. Almost for all parts considered in this study, there is a reduction in lead time which is clearly shown by the bars in the bar diagram for parts P1 - P8. 


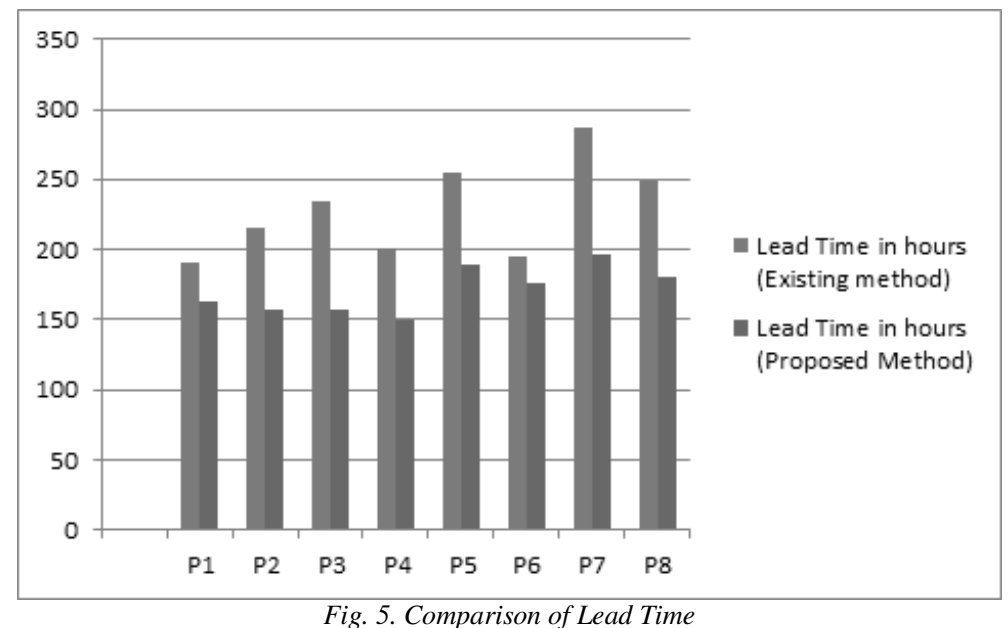

The percentage comparison is clearly explained for all the eight parts, as shown in Figure 6. It is understood that the minimum percentage reduction of lead time is $10.92 \%$ for the part P6 and next reduction is $14.55 \%$ for the part P1, the parts P4 $(25.71 \%)$ and P5 (25.96\%)are having a similar reduction. Similarly, the parts P2 $(27.29 \%)$ and P8 (27.39 \%) are having an almost closer reduction in lead time and the parts P7 (31.68 \%) and P3 $(33.41 \%)$ and having a minute difference in terms of percentage reduction in lead time because of their similarity in operations and process times.

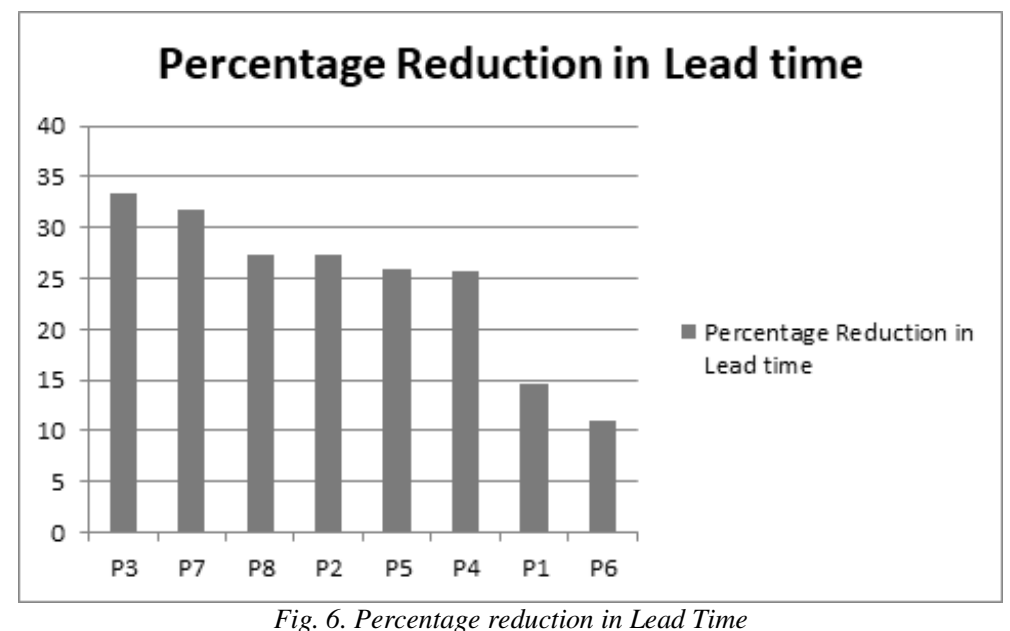

\section{Conclusion and Future Scope}

In this research work, it was attempted to minimize the lead time of the manufacturing process by eliminating all possible Non Value Added activities with the help of value stream mapping process as one of the management decision making processes for achieving customer satisfaction through the implementation of modern techniques and also by using methods like cellular manufacturing and the single-piece flow. The parts (P1 - P8) considered are for case study purposes in a batch type steel industry located in the southern part of India. The chosen industry is placed under small and medium enterprises (SME) category based on its annual income as for South Indian environment conditions. From the interpretation of results, it is observed that the percentage of reduction in the total lead time for each batch of parts considered in this study can be achieved to an average of $24.613 \%$. Since there is a considerable reduction in lead time, the company's total profit could be increased, which in turn helps in processing more customer orders. Therefore, customer satisfaction is improved, and further expansion is possible in the near future. The following points could be taken well for furthering the research work.

The lead time can be further reduced by focusing on the reduction of transportation time between the supplier, factory and customer. The following suggestive measures can be considered as a future scope. Implementation of these steps will prevent the occurrence of an error (NVAs):

- The fixtures should be designed so that the operator could avoid a mistake while mounting the part. 
- The quality checking can be done immediately in the machine only using an automatic gauge. A buzzer should be used to indicate an error.

- If any error is detected, the process should be stopped, and the source of the error should be detected and rectified before starting the processing of the next part.

\section{References}

Ashif, M., Goyal, S., \& Shastri, A. (2015). Implementation of Lean Tools-Value Stream Mapping \& SMED for Lead Time Reduction in Industrial Valve Manufacturing Company. Applied Mechanics and Materials, 813-814, 1170-1175. doi:10.4028/www.scientific.net/amm.813-814.1170

Carmignani, G. (2017). Scrap value stream mapping (S-VSM): A new approach to improve the supply scrap management process. International Journal of Production Research, 55(12), 3559-3576. doi:10.1080/00207543.2017.1308574

Chen, L., \& Meng, B. (2010). The Application of Value Stream Mapping Based Lean Production System. International Journal of Business and Management, 5(6). doi:10.5539/ijbm.v5n6p203

Doğan, N. Ö, \& Unutulmaz, O. (2014). Lean production in healthcare: A simulation-based value stream mapping in the physical therapy and rehabilitation department of a public hospital. Total Quality Management \& Business Excellence, 27(1-2), 64-80. doi:10.1080/14783363.2014.945312

Duggan, K. J., \& Healey, T. (2016). Operational excellence in your office: A guide to achieving autonomous value stream flow with lean techniques. Boca Raton: CRS Press Taylor et Francis Group.

Forno, A. J., Pereira, F. A., Forcellini, F. A., \& Kipper, L. M. (2014). Value Stream Mapping: A study about the problems and challenges found in the literature from the past 15 years about application of Lean tools. The International Journal of Advanced Manufacturing Technology,72(5-8), 779-790. doi:10.1007/s00170-014-5712-z

Gergin, Zeynep \& Akburak, Dilek \& Gültekin, Selinay \& Kara, Batuhan. (2017). Application Of Lean Management To Ground Operations Processes Of An Airline Company-A Value Stream Mapping Study, International Symposium for Production Research 2017, 13 - 15 September 2017, Vienna.

Huang, Z., Kim, J., Sadri, A., Dowey, S., \& Dargusch, M. S. (2019). Industry 4.0: Development of a multi-agent system for dynamic value stream mapping in SMEs. Journal of Manufacturing Systems, 52, 1-12. doi:10.1016/j.jmsy.2019.05.001

Jeong, B. K., \& Yoon, T. E. (2016). Improving IT process management through value stream mapping approach: A case study. Journal of Information Systems and Technology Management, 13(3). doi:10.4301/s180717752016000300002

Joshi, H., Goyal, B., \& Tomar, P. (2020). Application of Value Stream Mapping in Induction Motors Making Industry to Develop Current State Map and Identify Wastes. Industrial Engineering Journal, 13(6). doi:10.26488/iej.13.6.1235

King, J.R. (1980). Machine-component grouping in production flow analysis: an approach using a rank order clustering algorithm, International Journal of Production Research, 18 (2), 213-232.

Klimecka-Tatar, D. (2018). Context of production engineering in management model of Value Stream Flow according to manufacturing industry, Production Engineering Archives, 21(21), 32-35. doi: https://doi.org/10.30657/pea.2018.21.07

Kocsi, B., \& Oláh, J. (2017b). Potential connections of unique manufacturing and industry 4.0. Logforum, 13(4), 389-400. doi: 10.17270/J.LOG.2017.4.1

Norton, A., \& Fearne, A. (2009). Sustainable value stream mapping in the food industry. Handbook of Waste Management and Co-Product Recovery in Food Processing, 3-22. doi:10.1533/9781845697051.1.3

Krykavskyy, Y., Pokhylchenko, O., \& Hayvanovych, N. (2019). Supply chain development drivers in industry 4.0 in Ukrainian enterprises. Oeconomia Copernicana, 10(2), 273-290. https://doi.org/10.24136/oc.2019.014

Maszke, A., Dwornicka, R., \& Ulewicz, R. (2018). Problems in the Implementation of the Lean Concept at a Steel Works - Case Study, MATEC Web Conf., vol. 183, p. 01014.

Mazur, M., \& Momeni, H. (2019). LEAN Production issues in the organization of the company results, Production Engineering Archives, 22(22),50-53.doi:https://doi.org/10.30657/pea.2019.22.10

Nguyen, M. (2018). A New Decision Making Model based on the Made in Vietnam Lean Management Philosophy. Economics and Sociology, 11(1), 44-60. doi:10.14254/2071-789X.2018/11-1/3

Nowicka-Skowron, M. \& Ulewicz, R. (2016). Problems in the Implementation of Lean Concept in The Metal Industry Companies, 25th Anniversary International Conference On Metallurgy And Materials, 19621967.

Nwabueze, U., \& Mileski, J. (2018). Achieving competitive advantage through effective communication in a global environment. Journal of International Studies, 11(1), 50-66. doi:10.14254/2071-8330.2018/11-1/4 
Oláh, J., Szolnok, Á., Nagy, Gy., Lengyel, P., \& Popp, J. (2017a). The Impact of Lean Thinking on Workforce Motivation: A Success Factor at LEGO Manufacturing Ltd. Journal of Competitiveness, 9 (2), 93-109. doi: 10.7441/joc.2017.02.07

Rother, M., \& Shook, J. (2009). Learning to see: Value-stream mapping to create value and eliminate muda; a lean tool kit method and workbook. Cambridge, MA: The Lean Enterprise Institute.

Womack, J. P., Jones, D. T., \& Roos, D. (2007). The machine that changed the world. London: Simon \& Schuster. Kevin J. Duggen, Creating Mixed Model Value Stream: Practical Lean Techniques for Building to Demand, CRC Press, Taylor \& Francis Group, Boca Raton, 2002.

Pandian, S. R., \& Soltysova, Z. (2018). Management of Mass Customized Orders Using Flexible Schedules To Minimize Delivery Times. Polish Journal of Management Studies, 18(1), 252-261. doi:10.17512/pjms.2018.18.1.19

Pandya Hardik B., Shah Sagar I. (2015). Lean Manufacturing Implementation Using Value Stream Mapping In an Automotive Industry. International Journal of Advance Engineering and Research Development, Volume 2, Issue 5, May -2015, pp 812- 822.

Pisar, P., \& Bilkova, D. (2019). Controlling as a tool for SME management with an emphasis on innovations in the context of Industry 4.0. Equilibrium. Quarterly Journal of Economics and Economic Policy, 14(4), 763-785. https://doi.org/10.24136/eq.2019.035

Rajnoha, R., Dobrovič, J., Gálová, K. (2018). The Use of Lean Methods in Central Eastern European Countries: the Case of Czech and Slovak Republic. Economics and Sociology, 11(2), 320-333. doi:10.14254/2071789X.2018/11-2/22

Santosh B Dighe \& Abhay Kakirde, (2014). Lean Manufacturing Implementation using Value Stream Mapping: A Case Study of Pump Manufacturing Company. International Journal of Science and Research, 3(6), 2492-2498.

Saraswat, P., \& Kumar, D. (2014). Application of Value Stream Mapping Tool to Reduce Wastes in Bearing Industry. International Journal of Recent Advances in Mechanical Engineering,3(4), 97-103. doi:10.14810/ijmech.2014.3409

Schmidtke, D., Heiser, U., \& Hinrichsen, O. (2014). A simulation-enhanced value stream mapping approach for optimization of complex production environments. International Journal of Production Research, 52(20), 6146-6160. doi:10.1080/00207543.2014.917770

Tran, T., Luu-Nhan, K., Ghabour, R., \& Daroczi, M. (2020). The use of Lean Six-Sigma tools in the improvement of a manufacturing company - case study, Production Engineering Archives, 26(1), 30-35. doi: https://doi.org/10.30657/pea.2020.26.07

Zimon, D. (2017). The influence of quality management systems for improvement of logistics supply in Poland. Oeconomia Copernicana, 8(4), 643-655. https://doi.org/10.24136/oc.v8i4.39 